\title{
A Study of Factors Influencing the Problem-solving Skills of Engineering Students
}

\author{
Sita L. Bhadargade ${ }^{1}$, Kaushik M. ${ }^{2}$, Gopalkrishna Joshi ${ }^{3}$ \\ ${ }^{1,2}$ School of Electronics and Communication Engineering, KLE Technological University, Hubballi, Karnataka, India \\ ${ }^{2}$ Centre for Engineering Education Research, KLE Technological University, Hubballi, Karnataka, India \\ 'sitalb@ kletech.ac.in \\ ${ }^{2}$ kaushik@kletech.ac.in \\ ghjoshi@kletech.ac.in
}

\begin{abstract}
Problem-solving skill is one of the essential attributes of an engineering graduate. It refers to the ability of the person to analyse a given problem and offer the best solution within the constraints. Engineering curriculum has the mandate of equipping students with skills and competencies in problemsolving. Several factors influence the problemsolving skills in addition to the technical skills and competencies offered through curricular interventions. Psychological factors, which are habitual patterns of behaviour, thought and emotion, also influence problem-solving skills. This study focuses on investigating the influence of psychological factors like motivation, perception, stress, team working skills, learning styles, general self-efficacy on problem-solving skills of engineering students. This study focused on first-year students of undergraduate engineering program registered for a course titled Engineering Exploration. This course is a three-credit multidisciplinary course that effectively uses Activity-Based Learning (ABL), Design-Based Learning (DBL) and Project-Based Learning (PBL) pedagogical practices. The data collected for the study was through interviews and the use of well-structured questionnaires administered to first-year students
\end{abstract}

\section{Sita L. Bhadargade}

School of Electronics and Communication Engineering, KLE Technological University, Hubballi, Karnataka, India sitalb@ kletech.ac.in enrolled for the course offered at the university. Results show that the psychological factors of students like motivation, perception, general selfefficacy and teamwork skills have a positive influence on problem-solving skills, while stress has a negative effect. However, the difference in learning styles does not influence problem-solving skills.

Keywords: Problem-solving skills, Project-Based Learning, Engineering Design Process, First-year Engineering, Graduate Attributes.

\section{Introduction}

Engineering problem-solving is one of the vital graduate attributes (Washington Accord). The ability to identify, formulate, and solve an engineering problem is the characteristic of this graduate attribute irrespective of engineering discipline (Jonassen D et al. 2006). Accordingly, it also figures as a prominent program outcome for engineering program accreditation bodies all over the world (ABET, NBA).

A study by World Economic Forum on employability skills with accelerated innovation cycles concluded in its report that cognitive ability, systems thinking and complex problem-solving would be few of the top skills that today's education system must address. (Hassan S et al. 2012). The importance and emphasis on problem-solving skills in the undergraduate engineering curriculum are wellstated better in these references. 
On the other hand, Indo Universal Collaboration for Engineering Education - Industry Teaching Fellow (IUCEE ITF) in its report on employability of Engineering Graduates in India (2017) mentioned that the gap between industry requirements and graduate capabilities are increasing annually and further states that $60 \%$ of engineering graduates are unemployable.

Statistics have shown by All India Council for Technical Education (AICTE dashboard) reflects that an average of only $17.9 \%$ of students is able to get placement in five years between 2013 and in 2018 .

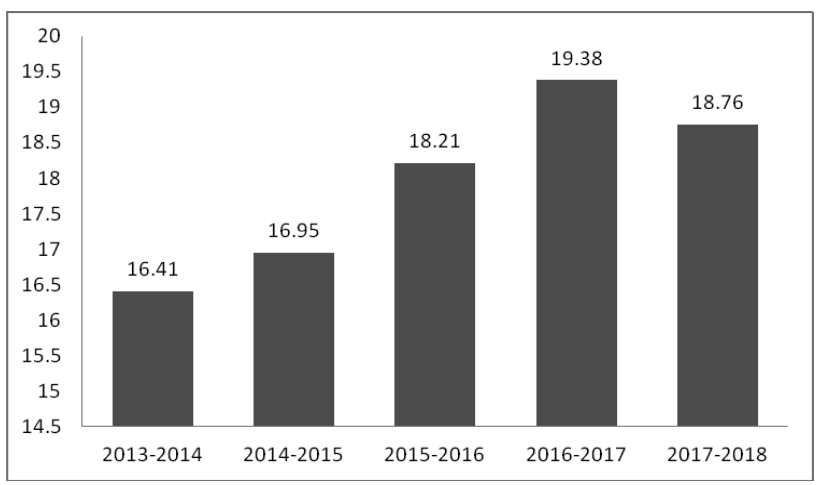

Fig. 1: AICTE placement statistics from 2013 to 2018

Fig.1, shows the placement record of five academic years during this period. Fresh engineers lacking problem-solving skills is a general phenomenon irrespective of countries (Ryan, R M et al. 2009). Although many of the pedagogies like cooperative problem-based learning (Mohd-Yusof K et al. 2011) project-based learning (Jayaram, S. 2014), designbased learning is in practice to improve problemsolving skills, research concludes that improvement is not satisfactory since very less attention was given to student diversity. Demographical factors, psychological factors and socio-cultural factors are the factors that bring diversity among students.

This motivated the authors to investigate the factors other than technical competencies that affect problem-solving skills. Literature reflects that factors including psychological, demographic and sociocultural characteristics, influence the problemsolving skills. Through this study, authors propose to limit the investigation to the influence of psychological factors on problem-solving skills of first-year engineering students. Thus formulated the research question as 'How do psychological characteristics influence the problem-solving skills of first-year engineering students?'
The motivation behind the research question is that a clear understanding of the characteristics of a student or learner will enable educators to design better teaching environments that facilitate learning and improve problem-solving skills.

The further section of the paper shows the literature survey part, that emphasise on systematic way of organising the literature and representing the literature map, followed with the methodology adopted comprising the details of people and procedures involved in the research, findings and inferences.

\section{Literature review}

Literature survey helped the authors to understand the types of problems (Jonassen D et al. 2006), skills required to solve different types of problem, what pedagogies have been used across the globe to improve problem-solving skills (Belski 2011, Hassan S et al. 2012, Heller et al. 1992) and what are the various factors that affect problem-solving skills? (Hutchison et al. 2006, Makewa et al. 2012, Felder R. M et al. 1988 Gholami et al. 2013). Fig. 2 shows the thematically arranged literature map that describes the various dimensions of pertinent information collected to arrive at the specific research question.

Information was gathered from four different perspectives, including, what kind of problems do an engineer solve? What skills are required for an engineer to solve workplace problems? What is the difference between the problem-solving approach, followed by experts and novices? What are the different models of problem-solving? What pedagogies are currently adopted in academia that focuses on improving problem-solving skills? What are the factors that influence the problem-solving skills of students?

In the context of Indian engineering education system, research in the direction of investigating the factors that influence problem-solving skills are worth examining. This motivated authors to investigate the impact of psychological factors on problem-solving skills of first-year engineering students.

Accordingly, the following research question is formulated: 'How do psychological characteristics like motivation, perception, stress, teamwork, selfefficacy and learning styles influence the problemsolving skills of first-year engineering students?' 


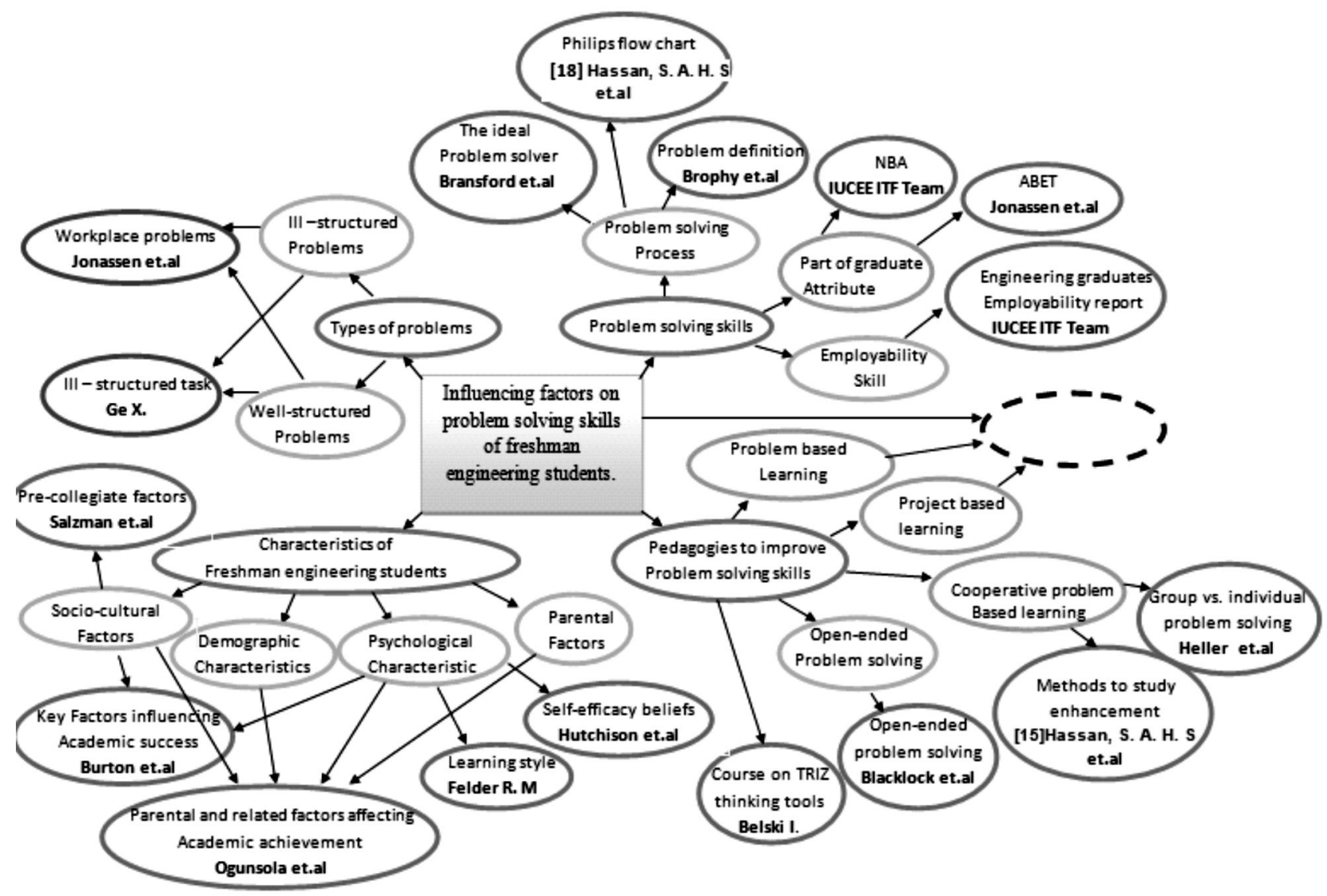

Fig.2 : Literature map

\section{Methodology}

The purpose of our research is to study the existing relationship between psychological characteristics of students and the problem-solving approach and not to control or manipulate the variables. Therefore, the research design that is chosen is co-relational. The statistical correlation test is used to describe and measure the degree of association between the variables. The co-relational statistical tests determine the tendency or pattern for two sets of data to vary consistently.

\section{A. Sample and site}

In order to carry out research, a first-year course titled Engineering Exploration was considered. This course is a three-credit multidisciplinary course that effectively uses ABL, DBL and PBL pedagogical practices. The data collection was done through interviews and the use of well-structured questionnaires administered to first-year students enrolled in the course, KLE Technological University, Hubballi. A total of thirty five students participated in the interview process. All participants were volunteers, whose anonymity was guaranteed and received no compensation.

The responses were statistically analysed to study the correlation between the psychological factors of students like motivation, learning style, self-efficacy, stress, perception, teamwork skills and their problemsolving skills.

\section{B. Data gathering strategies}

The first step is to define the psychological factors considered and problem-solving skills clearly. Appropriate scales for capturing the psychological factors and problem-solving skills of the students were selected. Questionnaires and scoring schemes were designed to capture the psychological factors and problem-solving skills.

\section{1) Capturing problem-solving skills}

The ability to come up with the best solution by analyzing the situation and considering all the 
constraints, available resources and consequences define the problem-solving skill. The IDEAL model of problem-solving process for capturing the problem-solving skills of the students was considered for the study.

For each step, questions were asked and based on the responses scores were given for each step, and the total score was computed.

Table 1. Problem-solving skills scale as shown in Fig 3. (Bransford, J. D et al. 1993)

\begin{tabular}{|l|l|}
\hline \multicolumn{1}{|c|}{ Steps } & \multicolumn{1}{c|}{ Description } \\
\hline $\begin{array}{l}\text { I (Identifying } \\
\text { problems and } \\
\text { Opportunities) }\end{array}$ & $\begin{array}{l}\text { Positive attitude while solving the } \\
\text { problem and seeing problems as an } \\
\text { opportunity to do something creative }\end{array}$ \\
\hline D( Define goals) & $\begin{array}{l}\text { Setting clearly defined goals and } \\
\text { objectives. T he objectives defined } \\
\text { should b e SMART(specific, } \\
\text { measurable, achievable, realistic, } \\
\text { timely), gather necessary } \\
\text { information }\end{array}$ \\
\hline $\begin{array}{l}\text { E(Explore possible } \\
\text { strategies) }\end{array}$ & $\begin{array}{l}\text { Seeing the problem from different } \\
\text { perspectives, finding out different } \\
\text { paths/strategy to achieve a } \\
\text { goal ,learning new skills/tools }\end{array}$ \\
\hline $\begin{array}{l}\text { A (Anticipate } \\
\text { Outcomes and Act) }\end{array}$ & $\begin{array}{l}\text { Addressing the consequences of the } \\
\text { solution proposed and do the } \\
\text { required changes }\end{array}$ \\
\hline $\begin{array}{l}\text { L (Look back and } \\
\text { learn) }\end{array}$ & $\begin{array}{l}\text { Look at the effects of the } \\
\text { implemented solution, flexible } \\
\text { thinking }\end{array}$ \\
\hline
\end{tabular}

\section{2) Capturing psychological factors}

Psychological factors are habitual patterns of

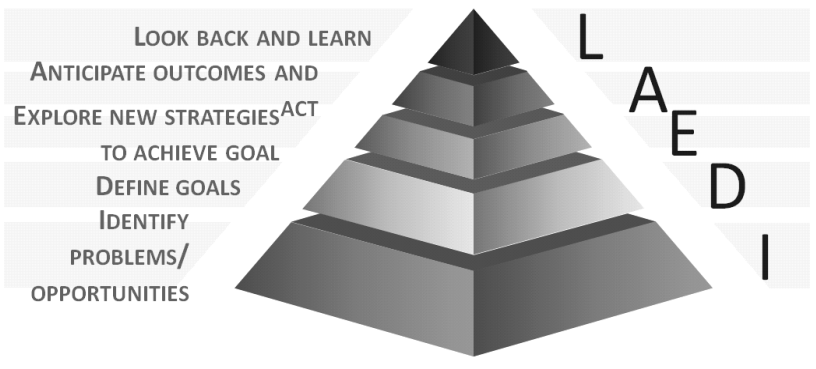

Fig. 3 : IDEAL model of problem solving (Bransford, J. D et al. 1993)

behaviour, thought, and emotion. These characteristics are aspects of personality that are relatively stable over time, differ across individuals, are relatively consistent over situations, and influence behaviour. Psychological factors considered for the research are motivation, stress, general self-efficacy, perception, teamwork skills and learning styles.

\section{A) Capturing Motivation}

Motivation is the reason for people's actions, willingness and goals. Academic Motivation Scale (AMS) for capturing the motivation of students was considered.

For each element, questions were asked and based on the responses scores were given for each element, and the total score was computed. The details of scale and description are shown in table 2 .

\section{B) Capturing Perception}

Perception is defined as the way in which something is regarded, understood, or interpreted. Here student perception of problem-solving skills that includes students' understanding of what problem-solving skills are and why they are essential is cosidered. The data has been collected based on the below-given scale. (Wismath $\mathrm{S}$ et al. 2014) For each step, questions were asked and based on the responses scores were given for each step, and the total score is computed. The details of the components and its description is shown in table 3 .

C) Capturing Teamwork skill

Table 2. Motivation scale (Utvaer et al. 2016)

\begin{tabular}{|c|l|}
\hline Components & \multicolumn{1}{|c|}{ Description } \\
\hline Knowledge & $\begin{array}{l}\text { Assesses the desire to perform a } \\
\text { activity for the pleasure and } \\
\text { satisfaction experienced while } \\
\text { learning }\end{array}$ \\
\hline Accomplishment & $\begin{array}{l}\text { Assesses the desire to perform an } \\
\text { activity for the pleasure and } \\
\text { satisfaction experienced from } \\
\text { accomplishment or creation }\end{array}$ \\
\hline Stimulation & $\begin{array}{l}\text { Measures the desire to perform an } \\
\text { activity in order to experience } \\
\text { stimulation }\end{array}$ \\
\hline Identified & $\begin{array}{l}\text { Assesses the desire to perform } \\
\text { activities in order to gain a sense of } \\
\text { importance and personal value }\end{array}$ \\
\hline Introjected & $\begin{array}{l}\text { Assesses the experience of pressure } \\
\text { and guilt among students. }\end{array}$ \\
\hline Extrinsic & $\begin{array}{l}\text { Measures wheth students } \\
\text { participate in activities to avoid } \\
\text { negative consequences or achieve } \\
\text { rewards }\end{array}$ \\
\hline Amotivation & $\begin{array}{l}\text { Assesses the experience of a lack of } \\
\text { motivation }\end{array}$ \\
\hline
\end{tabular}


Table 3. Perception scale (Wismath et al. 2014)

\begin{tabular}{|c|l|}
\hline Component & \multicolumn{1}{c|}{ Description } \\
\hline Confidence & $\begin{array}{l}\text { This involves students' perceptions of their } \\
\text { own skill and confidence as problem solvers }\end{array}$ \\
\hline $\begin{array}{c}\text { Metacognition } \\
\text { and self- } \\
\text { awareness }\end{array}$ & $\begin{array}{l}\text { This includes knowledge about one's } \\
\text { personal thinking style and strengths and } \\
\text { weaknesses, as well as knowledge about } \\
\text { various strategies to use in problem -solving } \\
\text { and process knowledge, such as which } \\
\text { strategies to use when and why. }\end{array}$ \\
\hline $\begin{array}{c}\text { Transfer to } \\
\text { academic work }\end{array}$ & $\begin{array}{l}\text { This involves whether students perceived that } \\
\text { the skills developed in the course are skills } \\
\text { that transfer to other areas of academic work. }\end{array}$ \\
\hline $\begin{array}{c}\text { Transfer beyond } \\
\text { the academy }\end{array}$ & $\begin{array}{l}\text { This involves student perception of skills that } \\
\text { would transfer from the course to their lives } \\
\text { outside of academia. }\end{array}$ \\
\hline
\end{tabular}

Teamwork skill is defined as the ability to work with a group of people cohesively, towards a common goal, creating a positive working atmosphere, and supporting each other to combine individual strengths to enhance team performance. The data has been collected based on the below-given scale. (Teamwork skills defined by IITK).

For each component, questions were asked and based on the responses scores were given for each component, and the total score is computed. The details of the components and its description is shown in table 4.

For each step, questions were asked and based on

Table 4. Teamwork scale

\begin{tabular}{|c|l|}
\hline Components & \multicolumn{1}{c|}{ Description } \\
\hline Contribution & $\begin{array}{l}\text { Contributing strategy suggestions, ideas } \\
\text { and efforts (most important) }\end{array}$ \\
\hline Cooperation & $\begin{array}{l}\text { Keeping all the team members updated with } \\
\text { regular communications, attending all group } \\
\text { meetings, active listening skills, learning } \\
\text { from teammates }\end{array}$ \\
\hline Communication & $\begin{array}{l}\text { Communicating openly with the team } \\
\text { members putting forward your thoughts } \\
\text { clearly and in an easy way to understand }\end{array}$ \\
\hline Being Respectful & $\begin{array}{l}\text { Listening attentivel y, giving due } \\
\text { consideration to the opinions of others, } \\
\text { commenting on the opinions respectfully }\end{array}$ \\
\hline $\begin{array}{c}\text { Being open \& } \\
\text { sharing thoughts }\end{array}$ & $\begin{array}{l}\text { Open and free exchange of ideas, don't take } \\
\text { criticism of your ideas personally }\end{array}$ \\
\hline Accepting team & $\begin{array}{l}\text { Being flexible, avoid co nflict and let two } \\
\text { different outlooks co -exist. It is important } \\
\text { that once a plan has been made, everyone } \\
\text { work to make it succeed. }\end{array}$ \\
\hline Being reliable & Being able to fulfil the assigned tasks \\
\hline
\end{tabular}

the responses scores were given for each step, and the total score is computed.

\section{D) Capturing Stress}

Stress is a state of mental or emotional strain or tension resulting from adverse or demanding circumstances. The data has been collected based on the scale as shown in table 5 .

Table 5. Stress scale

\begin{tabular}{|c|l|}
\hline Stressors & \multicolumn{1}{|c|}{ Examples } \\
\hline Academic & $\begin{array}{l}\text { Attending classes, completing the } \\
\text { readings, writing papers, managing } \\
\text { projects, and preparing for exams }\end{array}$ \\
\hline Personal & $\begin{array}{l}\text { roommate problem, peer pressure, } \\
\text { weight gain, physical appea rance, } \\
\text { relationships }\end{array}$ \\
\hline Family & $\begin{array}{l}\text { Family's expectations for good } \\
\text { grades, family problems }\end{array}$ \\
\hline Financial & Money problem \\
\hline Future & Uncertainty about the career path \\
\hline
\end{tabular}

For each component, students were asked how often (every day/always/ sometimes/ once in a while/ never) they experience stress because of that particular stressor. The students were also asked how and to what extent it affected their performance in engineering exploration course. Based on their responses, scores were given for each stressor, and the total score was computed.

\section{E) Capturing Self-Efficacy}

Self-efficacy is the individuals' belief in their ability to perform well in a variety of situations. General Self-Efficacy (GSE) Scale for capturing the self-efficacy of the students was considered. (Schwarzer R et al. 1995) This scale is a self-report measure of self-efficacy.

Scoring:

\begin{tabular}{|c|c|c|c|c|}
\hline & $\begin{array}{c}\text { Not at } \\
\text { all }\end{array}$ & $\begin{array}{c}\text { Hardly } \\
\text { true }\end{array}$ & $\begin{array}{c}\text { Moderately } \\
\text { true }\end{array}$ & $\begin{array}{c}\text { Exactly } \\
\text { true }\end{array}$ \\
\hline $\begin{array}{c}\text { All } \\
\text { Questions }\end{array}$ & 1 & 2 & 3 & 4 \\
\hline
\end{tabular}

The total score is calculated by finding the sum of all items. For the GSE, the overall score ranges between 10 and 40, with a higher rating indicating more self-efficacy.

F) Identifying the preferred learning style

No-one has exclusively one single learning style or preference. Learners use all three methods to receive information. However, one or more of these receiving styles is normally dominant. Your learning style 
influences the way you understand information and solve problems.

VAK (Visual, Auditory and Kinaesthetic) learning style is considered in this study. The details of the learning styles and its description is shown in table 6 .

Table 6. VAK learning style (Gholami et al. 2013)

\begin{tabular}{|l|l|}
\hline Learning style & \multicolumn{1}{c|}{ Description } \\
\hline Visual & $\begin{array}{l}\text { This style involves the use of seen or observed } \\
\text { things, including pictures, diagrams, } \\
\text { demonstrations, displays, handouts, films, flip - } \\
\text { chart, etc. }\end{array}$ \\
\hline Auditory & $\begin{array}{l}\text { This style involves the transfer of information } \\
\text { through listening: to the spoken word, of self } \\
\text { or others, of sounds and noises. }\end{array}$ \\
\hline Kinesthetic & $\begin{array}{l}\text { This involves physical experience - touching, } \\
\text { feeling, holding, doing, practical hands -on } \\
\text { experiences }\end{array}$ \\
\hline
\end{tabular}

A questionnaire from vak-learn.com was taken to identify the preferred learning style of students .Their scores in all three categories were considered to study the correlation.

After clearly defining, establishing appropriate scales and designing the questionnaires and scoring schemes for capturing the psychological factors and problem-solving skills, the data is collected through the interview process.

\section{Results}

This chapter discusses the findings of the interview process. The statistical correlation test is used to describe and measure the degree of association between the variables. The correlational statistical tests determine the tendency or pattern for two sets of data to vary consistently. The subsequent section describes the correlation of all the psychological factors considered with problem-solving skills.

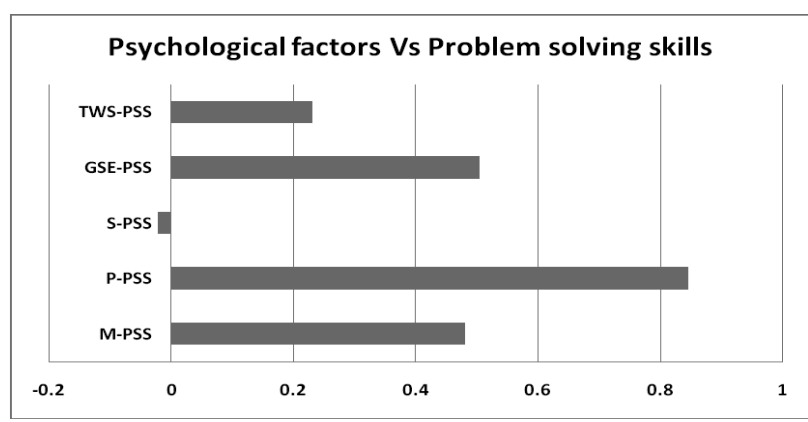

PSS-Problem Solving Skills, M-Motivation, P-Perception, S-Stress, GSE-General Self-Efficacy, TWS- Teamwork skills

Fig. 3 : Correlation psychological factors with problem solving skills (IDEAL model)
A) Psychological factors Vs problem-solving skills

Motivation, perception, general self-efficacy and teamwork skills correlated positively with the problem-solving skills. The correlation is highest for perception. Stress correlated negatively with problem-solving skills, as shown in fig. 3

While studying the influence of individual psychological factors, the influence of each component on various steps of the problem-solving process was studied. For this, each component of all the psychological factors is correlated with the IDEAL model of problem-solving skills.

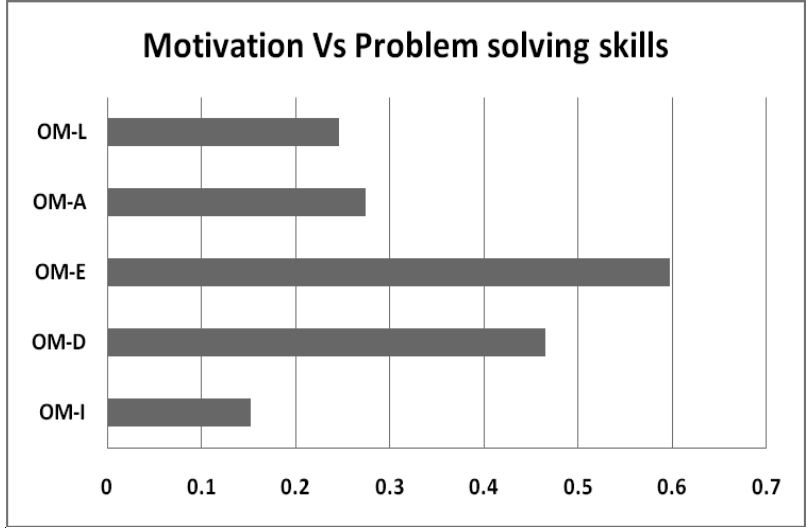

Fig. 4 :Correlation of motivation with problem solving skills (IDEAL model)

B) Motivation Vs Problem-solving skills

Motivation is positively correlated with all the steps in the problem-solving process. The students with high overall motivation score scored high in defining goals, exploring possible strategies and looking at the effects of the solution steps of the problem-solving process. Fig 4. displays the direction (positive or negative) as well as the extent to which motivation influences the steps involved in the problem-solving process.

Table 7. Correlation of components of motivation with problem-solving skills (IDEAL model)

\begin{tabular}{|c|c|c|c|c|c|c|c|}
\hline $\begin{array}{l}\text { Motivati } \\
\text { on }\end{array}$ & \multicolumn{4}{|c|}{ Autonomous } & \multicolumn{2}{|c|}{ Controlled } & $\begin{array}{c}\text { Amotiva } \\
\text { tion }\end{array}$ \\
\hline Median & \multicolumn{4}{|c|}{0.4480} & \multicolumn{2}{|c|}{0.4210} & -0.0420 \\
\hline $\begin{array}{l}\text { Problem- } \\
\text { solving } \\
\text { skills }\end{array}$ & $\mathrm{K}$ & $\mathrm{AC}$ & ST & ID & IN & EX & AM \\
\hline $\mathrm{I}$ & 0.54 & 0.08 & -0.28 & 0.24 & 0.24 & 0.21 & -0.20 \\
\hline $\mathrm{D}$ & 0.48 & 0.53 & -0.34 & 0.37 & 0.40 & 0.22 & -0.22 \\
\hline$E$ & 0.58 & 0.40 & -0.41 & 0.45 & 0.45 & 0.38 & -0.32 \\
\hline $\mathrm{A}$ & 0.52 & 0.65 & -0.41 & 0.48 & 0.38 & 0.20 & -0.29 \\
\hline $\mathrm{L}$ & 0.40 & 0.30 & -0.11 & 0.49 & 0.34 & 0.41 & -0.20 \\
\hline
\end{tabular}

K-Knowledge, AC-Accomplishment, ST-Stimulation,

ID-Identified, IN-Introjected, EX-Extrinsic, AM-Amotivation 
The correlation of autonomous motivation with problem-solving skills was highest compared to other categories of motivation. Among intrinsic motivation subscales, intrinsic motivation for knowledge achieved the highest mean score, whereas identified regulation achieved the highest mean score among extrinsic motivation subscales.

It is observed that motivation for knowledge has correlated highest with the score in step 'I'.This is the step where we need to gather more and more information related to the problem and see it as an opportunity to learn something new. The students who experienced pleasure and satisfaction in learning new things scored high in this step.

\section{2) Correlation of motivation with 'D' (Defining goals)}

It is observed that that motivation for accomplishment and knowledge has correlated highest with the score in D step .This is the step which involves gathering necessary information, setting multiple goals, which explains why the students who experienced pleasure in learning new things had a score in this step. This step involves clearly defining goals and setting multiple goals, which involves a lot of brainstorming, and therefore the students who experience pleasure in doing difficult academic activities scored high in this step.

3) Correlation of motivation with 'E' (Exploring possible strategies)

It is observed that motivation for knowledge has correlated highest with the score in E step. This is the step which involves learning new tools, exploring possible paths to achieve the goal and therefore, the motivation to learn new things help in this step. We can even see that amotivation has a greater impact on this step compared to other steps.

4) Correlation of Motivation with 'A' (Anticipating outcomes and Act)

In this case motivation for accomplishment has correlated highest with the score in A step. This is the step which includes systematically search for several issues that may create problem in future, giving attention to the smaller details and analyzing each and everything which is a quite difficult task and therefore the motivation for accomplishment helps in this step. Also, results reflect that amotivation has a greater impact in this step also.
5)Correlation of Motivation with 'L'( Look back and Learn)

It is observed that in the fifth row that motivation for identified has correlated highest with the score in $\mathrm{L}$ step. This is the step which includes looking for ways to improve the idea and future problems, applying the knowledge gained in some other field and this explains that the students who were motivated were because they understood the application and importance of the whole process and scored high in this step.

\section{C) Perception Vs Problem-solving skills}

Fig 5. shows the figure that displays the direction (positive or negative) as well as the extent to which perception influences the steps involved in the problem-solving process. Perception is positively correlated with all the steps in the problem-solving process. The students with high overall perception score, scored high in defining goals, exploring possible strategies and anticipating the outcome of the solutions steps of the problem-solving process.

Table 8. Correlation of components of perception with problem-solving skills (IDEAL model)

\begin{tabular}{|c|c|c|c|c|}
\hline $\begin{array}{l}\text { Perceptio } \\
\text { n }\end{array}$ & $\begin{array}{c}\text { Confidenc } \\
\text { e }\end{array}$ & $\begin{array}{c}\text { Metacognitio } \\
\text { n \& self- }\end{array}$ & $\begin{array}{c}\text { Transfe } \\
\text { r to }\end{array}$ & $\begin{array}{c}\text { Transfe } \\
\text { r }\end{array}$ \\
\hline $\begin{array}{l}\text { Problem- } \\
\text { solving } \\
\text { skills }\end{array}$ & & awareness & $\begin{array}{c}\text { academi } \\
\text { c work }\end{array}$ & $\begin{array}{c}\text { beyond } \\
\text { the } \\
\text { academ } \\
y \\
\end{array}$ \\
\hline $\mathrm{I}$ & 0.56 & 0.03 & 0.23 & 0.21 \\
\hline $\mathrm{D}$ & 0.46 & 0.50 & 0.48 & 0.29 \\
\hline$E$ & 0.58 & 0.59 & 0.58 & 0.30 \\
\hline $\mathrm{A}$ & 0.33 & 0.48 & 0.38 & 0.25 \\
\hline $\mathrm{L}$ & 0.38 & 0.15 & 0.40 & 0.42 \\
\hline
\end{tabular}

1) Correlation of Perception with 'I' (Identifying problems)

It is observed that in the first row that the confidence in one's problem-solving skills has correlated highest with the score in step I. This step involves having a positive attitude toward the problem and seeing it as an opportunity to learn and hence the students who were confident about their problemsolving skills and enjoyed solving new problems scored high in this step.

\section{2) Correlation of Perception with 'D' (Defining goals)}

It is observed that the second row that the Metacognition \& self-awareness has correlated 
highest in this step. This step involves clearly defining the goals, objectives and setting multiple goals which require a lot of thinking and decision making; this explains why metacognition \& self-awareness correlated highest in this step.

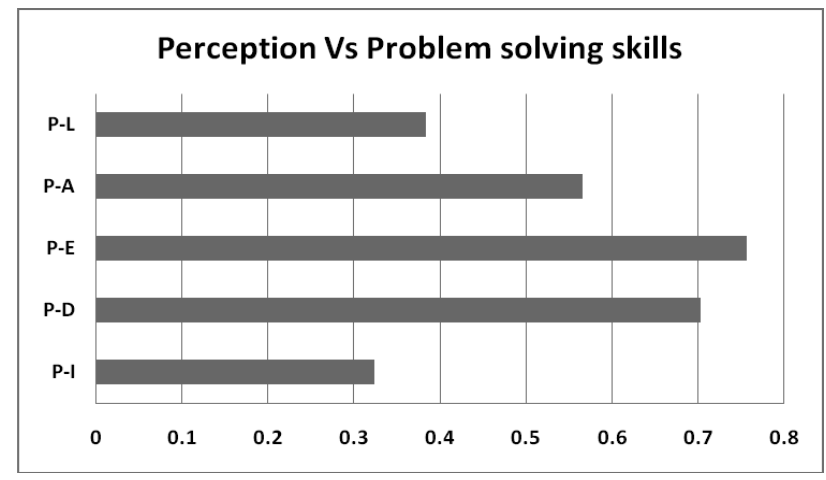

Fig. 5 : Correlation of perception with problem solving skills (IDEAL model)

3)Correlation of Perception with 'E' (Exploring possible strategies)

This step involves seeing the problem from different perspectives, finding out different paths to achieve the goals and learning new tools which involve a lot of thinking process and requires the student to be confident in his/her problem-solving skills, this is why the confidence, metacognition \& self-awareness and transfer to academic work component of perception correlated highest in this step(third row).

4) Correlation of Perception with 'A' (Anticipating outcomes and Act)

This step involves addressing the consequences and do the necessary changes which involve thinking and decision making; this is why the metacognition \& self-awareness component correlated highest in this step (fourth row).

5) Correlation of Perception with 'L' (look back and learn)

This step involves applying the knowledge gained in other fields; this is why the ability to transfer the knowledge in academic work and beyond academy correlates highest with the score in this step (fifth row).

D) Teamwork skills Vs Problem-solving skills

Fig. 6 shows the graph that displays the direction (positive or negative) as well as the extent to which Teamwork skills influences the steps involved in the problem-solving process. Teamwork skill is positively correlated with all the steps in the problemsolving process.

The students with high overall teamwork score, scored high in defining goals, exploring possible strategies and anticipating the outcome of the solutions steps of the problem-solving process.

1) Correlation of Teamwork skills with 'I' (identifying problems) score

This step involves understanding the need to solve the problem, surveying (talking to different stakeholders to understand the problem), which requires good communication skills and contribution of ideas. This correlation can be clearly seen in the first row.

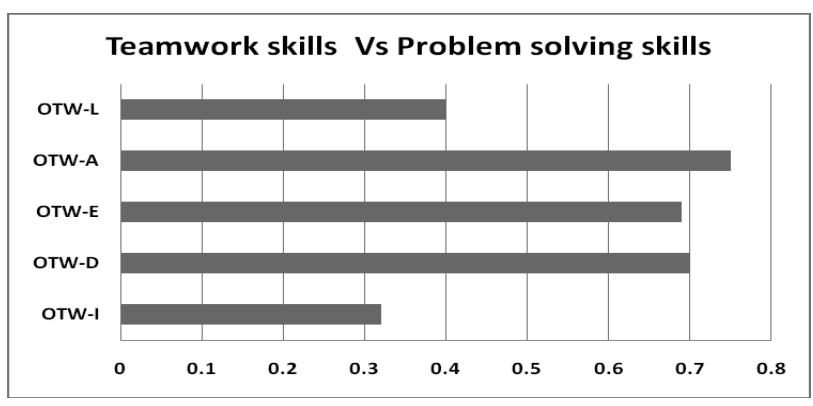

Fig. 6. : Correlation of Teamwork skills with problem solving skills (IDEAL model)

2) Correlation of Teamwork skills with 'D' (Defining goals) score

This step involves clearly defining goals and objectives, coming up with multiple goals, this phase involves a lot of discussions and idea generation and hence contributing ideas, attending team meetings and effectively communicating ones' ideas is important in this step .This correlation can be seen in the second row.

3) Correlation of Teamwork skills with 'E' (Exploring possible strategies) score

This step involves seeing the problem from different perspectives(by talking to different stakeholders and experts), finding out different paths to achieve the goals( by team discussions and gathering information), and learning new tools which requires, which requires contribution in the form of efforts and ideas, good communication skills, 
cooperation and actively listening the ideas. This correlation can be seen in the third row where cooperation, communication, contribution and being open and sharing thoughts have correlated highest with the E score.

4) Correlation of Teamwork skills with 'A' (Anticipating outcomes and act) score

This step involves addressing the consequences and making necessary changes, this step involves decision making and hence will require the team members to accept the team decision, and as this is a crucial phase of problem-solving, it also requires the team members to fulfil the assigned tasks. This correlation can be seen in the fourth row, where Accepting team decisions and being reliable have correlated highest with the A score.

5) Correlation of Teamwork skills with 'L' (Look back and learn) score

This step involves evaluating the solution by looking at its effects and coming up with ideas to improve the solution, which requires the open and free exchange of ideas and not taking criticism personally. This correlation can be clearly seen in the fifth row where communication and being open and sharing thoughts have correlated highest with the L score.

Table 9. Correlation of teamwork skills with problem-solving skills (IDEAL model)

\begin{tabular}{|c|c|c|c|c|c|c|c|}
\hline $\begin{array}{c}\text { Team } \\
\text { work } \\
\text { skills }\end{array}$ & $\begin{array}{c}\text { CON } \\
\text { T }\end{array}$ & $\begin{array}{c}\text { COO } \\
\text { P }\end{array}$ & $\begin{array}{c}\text { CO } \\
\text { MM }\end{array}$ & BR & $\begin{array}{c}\text { BO } \\
\text { S }\end{array}$ & $\begin{array}{c}\text { AT } \\
\text { D }\end{array}$ & BRL \\
\hline I & 0.54 & 0.08 & 0.54 & 0.24 & 0.24 & 0.21 & 0.23 \\
\hline D & 0.48 & 0.53 & 0.48 & 0.37 & 0.40 & 0.22 & 0.43 \\
\hline E & 0.58 & 0.65 & 0.58 & 0.45 & 0.59 & 0.27 & 0.54 \\
\hline A & 0.52 & 0.18 & 0.52 & 0.48 & 0.38 & 0.52 & 0.60 \\
\hline L & 0.32 & 0.34 & 0.48 & 0.20 & 0.41 & 0.30 & 0.32 \\
\hline
\end{tabular}

CONT-Contribution, COOP- Cooperation, COMMCommunication, B R-Being Respectful, BOS-Being Open \& Sharing thoughts, ATD- Accepting Team Decisions, BRL- Being Reliable

\section{E) Stress Vs Problem-solving skills}

The below-given graph displays the direction ( positive or negative) as well as the extent to which stress influences the steps involved in the problemsolving process.

The overall stress is negatively correlated to problem-solving skills, but in certain steps, stress is positively correlated that means there are certain phases of the problem-solving process where stress helps in coming up with a better solution.

Table10. Correlation of components of stress with problem-solving skills (IDEAL model)

\begin{tabular}{|c|r|r|r|r|r|}
\hline Stress & Academic & Personal & Family & Financial & Future \\
\cline { 1 - 6 } $\begin{array}{l}\text { Problem- } \\
\text { solving } \\
\text { skills }\end{array}$ & -0.34 & 0.09 & 0.15 & 0.24 & -0.07 \\
\hline I & -0.18 & 0.15 & 0.13 & 0.21 & 0.21 \\
\hline D & -0.31 & 0.16 & 0.21 & 0.06 & 0.20 \\
\hline E & -0.36 & -0.11 & 0.22 & 0.19 & 0.01 \\
\hline A & -0.06 & -0.07 & 0.24 & 0.36 & 0.02 \\
\hline L & \multicolumn{7}{|l}{} \\
\hline
\end{tabular}

All students found it stressful to manage projects along with other academic work (minor, term work, assignments, course project); they used to feel more stress when the deadline was near. They were unable to manage time. Their academic stress was affecting other aspects of life, but their personal life didn't affect their academics. Few students also felt stress once in a while to perform good and score well as engineering is an expensive degree; this fact reminds them of their responsibility. The students who have come from far away(different states) felt a little self stress to score well as they have spent so much money, and they have come so far.

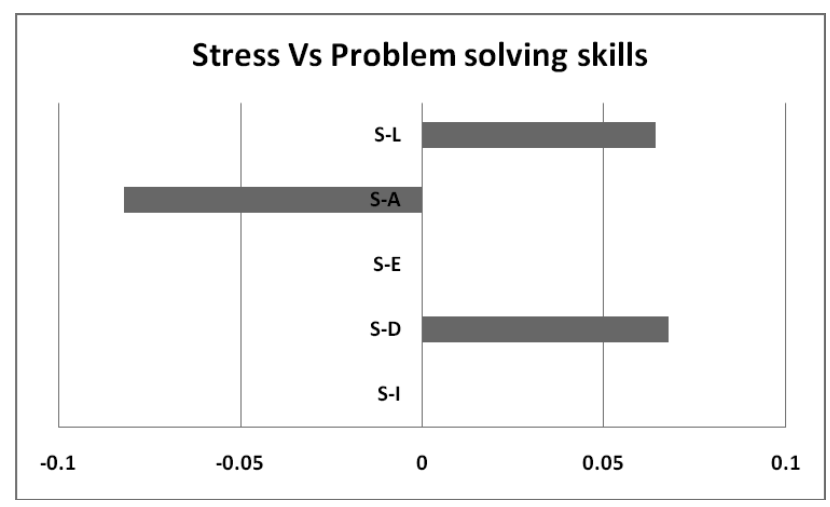

Fig.7. :Correlation of stress with problem solving skills

Few students also felt stress once in a while, thinking about their future or thinking about the career. The qualitative analysis of the data suggests that major stressors are academic stress and future stress.

F) General self-efficacy Vs Problem-solving skills

Fig 8. Shows the graph that displays the direction ( positive or negative) as well as the extent to which general self-efficacy influences the steps involved in the problem-solving process. 


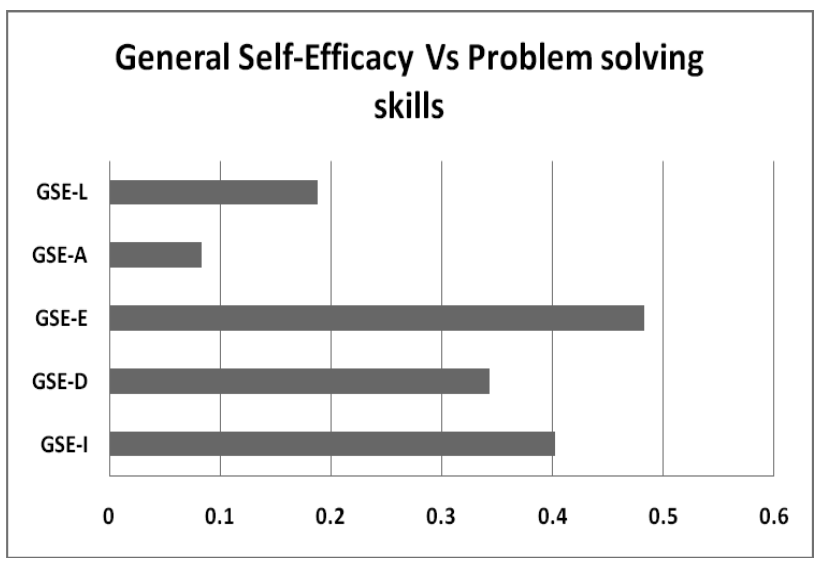

Fig. 8 : Correlation of General self-efficacies with problem solving skills

The students, who believe that they have the ability to perform well in a variety of situations more likely to see problems as an opportunity, talk to people and experts, explore different ways to achieve the goal and learn tools/skills necessary quickly.

G) Learning style Vs Problem-solving skills

Table 11. displays correlational values of learning styles with problem-solving skills.

\begin{tabular}{|c|c|c|c|}
\hline $\begin{array}{c}\begin{array}{c}\text { Learning } \\
\text { styles }\end{array} \\
\text { Problem- } \\
\text { solving skills }\end{array}$ & Visual & Auditory & Kinesthetic \\
\hline I & -0.41811 & -0.30965 & 0.696267 \\
\hline $\mathrm{D}$ & -0.3739 & -0.08427 & 0.407837 \\
\hline E & -0.24071 & -0.35654 & 0.535923 \\
\hline A & -0.56665 & -0.06528 & 0.650964 \\
\hline $\mathrm{L}$ & -0.05565 & -0.53575 & 0.543916 \\
\hline
\end{tabular}

Table 11. displays correlational values of learning styles with problem-solving skills.

Kinaesthetic learning style is the only learning style which correlates positively with problemsolving skills. This indicates that the students who prefer learning new things by doing it are better problem solvers and are more likely to enjoy solving new problems

No significant difference was observed in the problem-solving process followed by students with different preferred learning style.In this chapter, the analysis and interpretations of the data collected during the interview process were done. The further section discusses with the conclusion, limitation and future scope of the research.

\section{Conclusion}

Psychological factors affect problem-solving skills of students. Motivation, perception, general self-efficacy and teamwork skills have a positive influence on problem-solving skills. Improving these factors will help improve problem-solving skills. Stress has a negative effect on the problem-solving skills of students. Students find it stressful to manage projects along with other academic work (minor, term work, assignments, course project), they are unable to manage time, and this affects their solution. An effort in the direction to reduce the academic stress of students helps to improve problem-solving skills.

However, no significant difference was observed between the problem-solving skills of students with different preferred learning style.

Along with psychological factors, the study of other influencing factors and their co-relation helps the teacher to think of an appropriate pedagogy that helps to improve the problem-solving skills of students. Providing an experience of solving an illdefined problem through a PBL course like engineering exploration has given multiple benefits in the direction of improving problem-solving ability.

Since the sample was relatively homogenous, further examination of psychological factors and problem-solving skills in different student population in India would be helpful in understanding the correlation better. In addition, few factors were assessed at an ordinal level by using a 5 -point Likert scale. As such, the variables were treated as if metric even if they were not. Nevertheless, it is important to ensure that non-metric data are used appropriately in statistical techniques and to be aware that this represents a limitation.

The scope of this study is limited to only finding the psychological factors that influences the problem solving skills however there is a scope for research to include the student experiences during solving of different types of problems and based on which the facilitator can decide the suitable pedagogical techniques.

Psychological factors affect students' academics, and efforts should be to put into understanding student psychology and its effect on their academic performance. This will enable educators to design better teaching environments that facilitate learning 
and help all students to achieve success. This requires a lot of effort and time from the educators' side and cooperation from students.

\section{References}

[1] AICTE statistics https://www.facilities.aicteindia.org/dashboard/pages/dashboardaicte.php

[2] Baligar, P., Kavale, S., Kaushik, M., Joshi, G., \& Shettar, A. (2018, November). Engineering Exploration: A Collaborative Experience of Designing and Evolving a Freshman Course. In 2018 World Engineering Education ForumGlobal Engineering Deans Council (WEEFGEDC) (pp. 1-5). IEEE.

[3] Belski, I. (2011). TRIZ course enhances thinking and problem-solving skills of engineering students. Procedia Engineering, 9, 450-460.

[4] Blacklock, J. (2015). Teaching and Learning Open-Ended Problem-solving Throughout a New De-gree Program(Doctoral dissertation, Colorado School of Mines).

[5] Bransford, J. D., \& Stein, B. S. (1993). The IDEAL problem solver.

[6] Brophy, S. P., \& Li, S. (2011). Problem definition in design by first-year engineering students. In American Society for Engineering Education. American Society for Engineering Education.

[7] Burton, L. J., \& Dowling, D. G. (2009). Key factors that influence engineering students' academic success: A longitudinal study. In Proceedings of the Research in Engineering Education Symposium (REES 2009) (pp. 1-6). The University of Melbourne.

[8] Chaudhry, N., \& Rasool, G. (2012). A case study on improving problem-solving skills of undergraduate computer science students. World Applied Sciences Journal, 20(1), 34-39.

[9] Deci, E.L., \& Ryan, R.M. (2008). Facilitating optimal motivation and psychological wellbeing across life's domains. Canadian Psychology/ Psychologie Canadienne, 49(1), 14-23.
[10] Employability skills retrieved from h t t p :// i u c e e org/i u cee/w p content/uploads/2017/10/ITF_EmployabilityWhite Paper-Ver3.1.pdf

[11] Felder, R. M., \& Silverman, L. K. (1988). Learning and teaching styles in engineering education. Engineering education, 78(7), 674681.

[12] Ge, X., \& Land, S. M. (2003). Scaffolding students' problem-solving processes in an illstructured task using question prompts and peer interactions. Educational Technology Research and Development, 51(1), 21-38.

[13] Gholami, S., \& Bagheri, M. S. (2013). Relationship between VAK learning styles and problem-solving styles regarding gender and students' fields of study. Journal of Language Teaching and Research, 4(4), 700.

[14] Gholami, S., \& Bagheri, M. S. (2013). Relationship between VAK learning styles and problem-solving styles regarding gender and students' fields of study. Journal of Language Teaching and Research, 4(4), 700-707.

[15] Hassan, S. A. H. S., Yusof, K. M., Mohammad, S., Abu, M. S., \& Tasir, Z. (2012). Methods to study the enhancement of problem-solving skills in engineering students through cooperative problem-based learning. ProcediaSocial and Behavioral Sciences, 56, 737-746.

[16] Heller, P., Keith, R., \& Anderson, S. (1992). Teaching problem-solving through cooperative grouping. Part 1: Group versus individual problem-solving. American journal of physics, 60(7), 627-636.

[17] Hutchison, M. A., Follman, D. K., Sumpter, M., \& Bodner, G. M. (2006). Factors influencing the self-efficacy beliefs of first-year engineering students. Journal of Engineering Education, 95(1), 39-47.

[18] Jayaram, S. (2014). Implementation of Active Cooperative Learning and Problem-based Learning in an Undergraduate Astrodynamics Course. In 52nd Aerospace Sciences Meeting(p. 0065). 
[19] Jonassen, D., Strobel, J., \& Lee, C. B. (2006). Everyday problem-solving in engineering: Lessons for engineering educators. Journal of engineering education, 95(2), 139-151.

[20] Jonassen, D. H., \& Hung, W. (2015). All problems are not equal: Implications for problem-based learning. Essential readings in problem-based learning, 7-41.

[21] Kaushik, M., \& Joshi, G. (2016, December). Transitional Learning Style Preferences and Its Factors in Newer Generation Engineering Students. In 2016 IEEE 4th International Conference on MOOCs, Innovation and Technology in Education (MITE) (pp. 263267). IEEE.

[22] Kaushik, M., Baligar, P., \& Joshi, G. (2018). Formulating An Engineering Design Problem: A Structured Approach. Journal of Engineering Education Transformations.

[23] Kulkarni, N. N., Kaushik, M., \& Joshi, G. (2016, December). Engineering Profession: Understanding Freshman Perspective. In 2016 IEEE 4th International Conference on MOOCs, Innovation and Technology in Education (MITE) (pp. 332-337). IEEE.

[24] Makewa, L. N., Role, E., \& Otewa, F. (2012). Parental factors affecting academic achievement of grade six pupils in Kisumu city, Kenya. International Journal of Asian Social Science, 2(11), 1984-1997.

[25] Mohd-Yusof, K., Hassan, S. H. S., Jamaludin, M. Z., \& Harun, N. F. (2011). Motivation and Engagement of Learning in the Cooperative Problem-based Learning(CPBL) Framework. In American Society for Engineering Education. American Society for Engineering Education.

[26] Ogunsola, O. K., Osuolale, K. A., \& Ojo, A. O. (2014). Parental and related factors affecting students' academic achievement in Oyo State, Nigeria. International Journal of Social, Behavioral, Educational, Economic, Business and Industrial Engineering, 8(9), 3129-3136.

[27] Ramteke, I. V., \& Ansari, J. (2016). Stress and Anxiety among first-year and final year
Engineering students. Stress, 3(4).

[28] Rendell, D. L. (2014). The Stress Problem: Exploring the intersections of student stress, involvement, and problem-solving selfefficacy.

[29] Ryan, R.M., \& Deci, E.L. (2009). Promoting self-determined school engagement: Motivation, learning, and well-being. In K.R. Wentzel, \& A. Wigfield (Eds.), Handbook of school motivation (pp. 171-196). New York, NY: Routledge.

[30] Salzman, N., Ricco, G. D., \& Ohland, M. (2014). Pre-college engineering participation among first-year engineering students.

[31] Schwarzer, R., \& Jerusalem, M. (1995). Generalized Self-Efficacy scale. In J. Weinman, S. Wright, \& M. Johnston, Measures in health psychology: A user's portfolio. Causal and control beliefs (pp. 35-37). Windsor, UK: NFER-NELSON.

[32] Stres s s cale retrie ved from http://www.mycollegesuccessstory.com/acade mic-success-tools/top-college-stressors.html

[33] Taur, P. D. Effect of yoga on academic performance in relation to stress. Editorial Board, 5.

[34] Teamwork advantages retrieved from https://www.universalclass.com/articles/busine ss/critical-thinking-skills/advantages-ofteamwork-in-problem-solving-strategies.htm

[35] Teamwork skills retrieved from https://iitk.ac.in/new/teamwork-skills

[36] Utvær, B. K. S., \& Haugan, G. (2016). The academic motivation scale: dimensionality, reliability, and construct validity among vocational students. Nordic Journal of Vocational Education and Training, 6(2), 17-45.

[37] Vallerand, R. J., Pelletier, L. G., Blais, M. R., Briere, N. M., Senecal, C., \& Vallieres, E. F. (1992). The Academic Motivation Scale: A measure of intrinsic, extrinsic, and amotivation in education. Educational and psychological measurement, 52(4), 1003-1017. 
[38] Wismath, S., Orr, D., \& Zhong, M. (2014). Student Perception of Problem-solving Skills.
Transformative Dialogues: Teaching \& Learning Journal, 7(3). 